\title{
THE SLOW ROAD TO THE SOCIAL INVESTMENT PERSPECTIVE IN THE EUROPEAN UNION
}

\author{
Shannon Dinan \\ Université de Montréal
}

\begin{abstract}
The European Union has no unilateral legislative capacity in the area of social policy. However, the European Commission does play the role of guide by providing a discursive framework and targets for its 28 Member States to meet. Since the late 1990's, the EU's ideas on social policy have moved away from the traditional social protection model towards promoting social inclusion, labour activation and investing in children. These new policies represent the social investment perspective, which advocates preparing the population for a knowledge-based economy to increase economic growth and job creation and to break the intergenerational transmission of poverty. The EU began the gradual incorporation of the social investment perspective to its social dimension with the adoption of ten-year strategies. Since 2000, it has continued to set goals and benchmarks as well as offer a forum for Member States to coordinate their social initiatives. Drawing on a series of interviews conducted during a research experience in Brussels as well as official documents, this paper is a descriptive analysis of the recent modifications to the EU's social dimension. It focuses on the changes created by the Europe 2020 Strategy and the Social Investment Package. By tracing the genesis and evolution of these initiatives, the author identifies four obstacles to social investment in the European Union's social dimension.
\end{abstract}




\section{Introduction $^{1}$}

The European Union's (EU) social dimension is a policy area that has been subject to numerous transformations within the more general evolution of the Union. A notable transition is the growing importance conferred on the social investment perspective, as exemplified by the adoption of the Social Investment Package (SIP) in 2013. This innovative social policy approach may be contrasted with earlier approaches to social policy and represents a change from the social safety net to the springboard (SaintMartin 2000). Broadly speaking, the social investment perspective proposes welfare state recalibration in the form of long-term investment in human capital, especially policies investing in children (Jenson and Saint-Martin 2003; Esping-Andersen 2002).

The social investment perspective has been promoted to the EU as well as national governments by a variety of policy experts over the past 20 years. In spite of the fact the SIP represents an important affirmation of the social investment perspective, advocates of the perspective are only cautiously optimistic towards the policy. This article presents a qualitative descriptive analysis of advocates' and other actors' involvement with the SIP. By conducting a document analysis, the article traces how policy entrepreneurs have sought to influence the social agenda though publications and participation in institutional spaces. The article then seeks to understand how the adopted policy does not meet the expectations of policy entrepreneurs, social partners, and experts by explaining critiques of the policy.

To do so, this article provides an overview of the present state of social policy in the EU, and an assessment of the incorporation of the social investment perspective within the EU. The article identifies two intertwining trends. The first trend concerns the EU's adoption of ten-year strategies which has created a discursive framework for Member States. The second is the use of new governance and soft policy initiatives for social policy. These trends created a policy environment that fostered even greater exchange and learning among diverse constellations of actors, which in turn has allowed experts to promote their ideas within EU policy circles. The article argues that although experts have been able to put the social investment perspective on the policy agenda, four obstacles - outlined below - have nonetheless hindered policy innovation. These obstacles have limited the transition toward the social investment perspective within the EU, thereby generating the reticence towards their "success" expressed by key informants during the targeted interviews conducted in summer 2013.

The first two obstacles are 1) structural tension between social and economic policy in the European Union, and 2) political ambivalence toward the European social model. First, while the EU has always had a social component, Member States remain sovereign and the social dimension is only one part of a much larger, economically oriented organism. Social policies therefore often take a backseat to other issues. The second obstacle is a perceived lack of political will in the social dialogue. The third and fourth obstacles are, 3 ) expert critiques of how to best promote the social investment perspective, and 4) expert criticisms of whether of the Social Investment Package (SIP) in an appropriate a policy instrument. One set of critiques voiced by social investment advocates is linked to the content of the SIP. Organizations such as the European Anti-Poverty Network (EAPN) and the European Trade Union Confederation of the SIP remain critical of the lack of funding for social investment and underline the need for stronger frameworks and more policy coherence; their opposition weakened the enthusiasm for the SIP among decision-makers. A

\footnotetext{
${ }^{1}$ See Appendix for a list of key abbreviations.
} 
broader set of critiques disagrees with the SIP as a policy instrument. Specifically, certain social policy experts remain unconvinced that the social investment perspective is an adequate policy framework for atrisk groups, and their perspective sometimes prevailed.

\section{Investigative Approach}

The article identifies a change in the EU's social policy that has been shaped by the ability of stakeholders' and policy experts' to place their policy ideas and proposals on the policy agenda. Accordingly, the agenda setting approach is used loosely to include attention to policy entrepreneurs in the policy making process (Kingdon 1984). Documentation, including EU and stakeholder reports, shows that policy entrepreneurs have acted in key moments, such as during European presidencies and through policy papers, to push their ideas.

To understand how experts were able to exert their influence, the article conducts a document analysis complemented by the targeted interviews with policy experts conducted by the author in 2013. The author also gained perspective on the EU's social policies while at the European Social Observatory (OSE), which is known as a "reference point" for information on EU integration and the social dimension (TURI, 2015). The documentation includes official EU documents, position papers, and policy reports. Interviews were conducted to supplement the documentation. They highlight obstacles that have hindered the adoption of the social investment perspective in the EU. The interviewees were chosen to incorporate both public and private actors, including stakeholders of the social dimension, the authors of an influential opinion paper, and technocrats in the European Commission.

The structure of this paper is as follows. The first section of the paper begins by providing a brief description of the social investment perspective and its origins. The second section outlines the EU's social dimension, and presents broad trends in social policy through the adoption of ten-year strategies. The third section presents the Social Investment Package and its adoption, before expanding on interviews that assess and critique the policy. The fourth section discusses the four obstacles holding back a more holistic approach to the social investment perspective in the EU. Finally, the paper concludes with a review of the four obstacles that have impeded the adoption of the social investment perspective in the EU.

\section{The Social Investment Perspective}

Members of the European Union face important challenges linked to economic and societal change, including changing labour relations and demographics, inequality, poverty, immigration, and the need for reforms in education, pensions, and healthcare. Significant welfare state recalibration is therefore required and numerous specialists are of the opinion that the social investment perspective is one direction of change (Jenson 2010a; Palier 2010, 13-17; Hemerijck 2010, 304, 323).

Although Giddens coined the term “social investment state" in 1998 to refer to the New Labour party's reconfiguration of the social citizenship mix in Britain, Jenson and Saint-Martin demonstrate that the social investment perspective is much broader and inspired by both Nordic Europe and the Third Way (2003). The social investment perspective is not yet a fixed paradigm of thought. Nevertheless, the perspective 
generally considers social policy initiatives to be a "productive factor" and one of its main tenants is to prepare the population for the changing economy (Morel et al. 2012, 13; Cantillon 2011, 440; Palier 2014). The population is to be prepared through the notion of productive social policy including investment in human capital, activation policies for job training and by promoting employment and social inclusion (Jenson and Saint-Martin 2003). The perspective also posits that to maximize employment, priority must be given to investment over the entire life cycle. In viewing policies toward human capital as long-term investments (a productive factor contributing to instead of being a cost for economic growth), this perspective uses the welfare state and markets to move away from passive policies. Furthermore, the mechanism for provision in the social investment perspective is one of new governance (Saint-Martin 2000; Rhodes 1996). Whereas the post-war welfare state delivers provisions through Weberian bureaucracy, ${ }^{2}$ the social investment perspective is based on the notion of provision through partnership with non-state actors (Saint-Martin 2000, 50; Jenson 2012, 75).

The social investment perspective places particular emphasis on long-term investments in human capital, and especially policies which invest in children (Jenson 2012, 68; Esping-Andersen 2002, 19-20). These investments are meant to promote family stability, to solidify the generational contract, and to break the intergenerational transmission of poverty (Esping-Andersen 2002, 20-23; Jenson 2010a, 64). For example, policies that promote employment for lone mothers encourage social inclusion. These investments are meant to repair deficiencies in the system caused by the changing family unit and ineffective markets. Reducing the risks created by family and market deficiencies prepares the population - by providing children with stability and education - to contribute to society in the future (Daly 2012,282). Consequently, the perspective introduces a dual role for the welfare state of preparing the population while also repairing structural deficiencies. Through the prioritization of social investment strategies, the social investment perspective first prepares citizens to face the modern economy, which also introduces demands for civic responsibility ${ }^{3}$. Then, it repairs the structural problems linked to the welfare, which protects the population from recurring social injustices (Morel et al. 2012, 19; Palier 2010, 377, 383).

Experts have diverging opinions of the level of influence the social investment perspective has in the EU. Regardless, there is a general consensus that the perspective affects European social policy initiatives through the social dimension (Hemerijck 2012; Hemerijck et al. 2010b; Jenson 2010b; Kvist 2013). The gradual incorporation of the social investment perspective into the European Union's social dimension began in 1997 with the European Employment Strategy (Hemerijck 2012, 47; Hemerijck et al. 2010b, 303). Since then, the EU has reaffirmed its commitment to the perspective through various policies including the Lisbon Strategy, the Europe 2020 Strategy and the SIP (Hemerijck 2012; Jenson 2010b; Kvist 2013). To understand this process, the following section explains the EU's social dimension.

\footnotetext{
${ }^{2}$ Weberian bureaucracy refers to Max Weber's rational legal ideal-type of bureaucracy. Weber explains one means of legitimate state domination is through legislation. To ensure laws are implemented equally and impartially, career civil service systems are rigid hierarchies that hire civil servants based on merit as confirmed by either systematic examination or education. See, Weber, Max. 1971 [1922]. Économie et société. Tome 1. Librarie Pion. 320-331. ${ }^{3}$ This perspective changes the role of the state as well as citizen's duties and responsibilities. As Jenson explains, according to the prevailing logic of the social investment perspective, "[...] young people and adults have a duty as citizens to invest in their human capital by seeking education and training" $(2012,73)$.
} 


\section{The European Union's Social Dimension}

The EU's social policy initiatives, commonly known as the EU's social dimension, are intimately linked to its competences without qualifying as one itself. The EU can indirectly legislate social policy through affiliated competences, such as social protection, inclusion and cohesion. Article 9 of the Treaty on the Functioning of the European Union (TFEU) introduces a "horizontal clause" which acts as a guarantee to promote full employment, social protection, training and education, health and safety and to limit social exclusion (Marlier et al. 2010). Consequently, the EU has certain legislative abilities with regards to social policy. However, the coordination of social policy remains the sovereign right of Member States. There has been a progressive use of innovative forms of governance for social policy (Verdun and Tömmel 2009). By way of example, the use of cooperative modes of governance can be observed in the adoption of ten-year strategies including the Lisbon Strategy, which sought to govern the EU's "social model" through a social Open Method of Coordination (OMC), and the Europe 2020 Strategy.

\section{The Lisbon Strategy and Open Method of Coordination}

The EU has adopted two consecutive ten-year strategies: the Lisbon Strategy in 2000 followed by the Europe 2020 Strategy in 2010. These strategies set an agenda and priorities for the decade to come. The Lisbon Strategy prioritized making the Union "the most competitive and dynamic knowledge-based economy in the world, capable of sustainable economic growth with more and better jobs and greater social cohesion" (Armstrong 2010,54). The Strategy also set the tone for the social dimension by placing economic, employment, and social policies on a common level and highlighting the need to go beyond negative integration (Barcevičius et al. 2014, 19). Finally, one of the particularly notable innovations of the Lisbon Strategy was the Open Method of Coordination.

Supposedly modeled on the European Employment Strategy (EES), the OMC is considered a soft law that promotes voluntary Member State coordination through mutual learning, defining common objectives, creating indicators, benchmarking, and monitoring between participating Member States (Armstrong 2010; Barcevičius et al. 2014, 19-20; Europa 2014). Specifically, the OMC was meant to be a cooperative mode of governance, based on voluntarism that allows for mutual learning (Tömmel 2009, 18). Known as an experimental or innovative form of governance, the OMC can be contrasted with more traditional modes of governance, such as hierarchical governance, which implies a "command-compliance model" (Rhodes 1996; Sabel and Zeitlin 2008; Tömmel 2009, 29).

Initially, the Social OMC was built as three separate strands - pensions, social inclusion, and health and long-term care - for which Member States provided yearly reports to promote mutual surveillance (Marlier et al. 2010, 115, 225; Barcevičius et al. 2014). When the Lisbon Strategy was restructured in 2006, these strands were streamlined and united into a single portfolio (Barcevičius et al. 2014, 26). Despite this, European experts have classified the Social OMC as both a promising form of new governance and a disappointing failure (Zeitlin 2010; Zeitlin et al. 2014; de la Porte and Pochet 2012).

\section{The Europe 2020 Strategy and The European Semester}

While the Lisbon Strategy is known best for its governance innovations, the EU's second ten-year strategy (Europe 2020), is noticeable for its change in content, including the move towards the Social Investment Package. Europe 2020 states the general goal of strengthening growth in the EU through three "mutually reinforcing priorities": smart, sustainable and inclusive growth (European Union 2013a). The 
strategy is structured around three pillars: macroeconomic surveillance, fiscal surveillance, and thematic coordination (European Union 2013a). Europe 2020 also includes a number of social objectives. For instance, one can find various social objectives in Europe 2020's five targets, which pertain to employment, research and development, climate change and energy sustainability, education, the fight against poverty and the promotion of social inclusion. The strategy's seven flagship initiatives also include social initiatives such as Youth on the Move, an Agenda for New Skills and Jobs and a Platform Against Poverty (European Union, 2013a). To achieve its goals, the Europe 2020 Strategy revises the EU's system of governance by implementing a new structure for the supervision and consolidation of Member States, the European Semester. ${ }^{4}$ In this context of soft governance, the SIP was adopted. The following section explains the role expertise played in the adoption of the SIP as well as its key characteristics.

\section{The Social Investment Package (SIP)}

Expertise plays an important role in EU decision-making and experts were an important part of the elaboration of the Social Investment Package (SIP) as they consistently placed the issue of social investment on the policy agenda (Hartlapp et al. 2014). In this section, documentation and interviews are used to highlight how experts promoted their policy ideas on the social investment perspective. Thus we might look for the new ideas about social investment and advocacy of it by examining experts' publications, their participation in institutional spaces (such as European presidencies) and their involvement with advocacy groups.

Following the Portuguese presidency in 2000, which led to the Lisbon Strategy, the 2001 Belgian Presidency also furthered the EU's social dimension by commissioning a study elaborating a "new welfare architecture for $21^{\text {st }}$ century Europe" (Esping-Andersen et al. 2001). Frank Vandenbroucke, representative to the Belgian Presidency and former member of the Belgian Parliament ${ }^{5}$ (Socialistische Partij Anders, Belgium), explains the study eventually led to the publication of the book, Why We Need A New Welfare State in 2002. ${ }^{6}$ The central theme of the book, written by Gøsta Esping-Andersen and colleagues ${ }^{7}$ is to move away from traditional welfare state provision towards more active policies targeted towards investing in the capacities of workers and children (Hemerijck 2012, 47). Despite the existence of three welfare regimes within the EU, the authors explain that Member States can coordinate around common objectives, such as family and children, gender equality, and work life and retirement, through the social OMCwithout creating a universal European model (Esping-Andersen 2002,19). While the study, especially its

\footnotetext{
${ }^{4}$ For a detailed explanation of the European Semester, see Marlier et al. 2010 and Vanhercke 2013.

${ }^{5}$ Frank Vandenbroucke has held various ministerial positions within the Belgian government, including Deputy Prime Minister and Minister of Foreign Affairs (1994-1995), Minister of Social Affairs and Pensions (1999-2003), and Minister for Employment and Pensions (2003-2004).

${ }^{6}$ Interview Frank Vandenbroucke (Representative to the Belgian Presidency of the EU (2001), and former Minister of Social Insurance and Health Care), in conversation with author, Brussels, Belgium, July 17, 2013.

7 "A New Welfare Architecture for Europe” by Gøsta Esping-Andersen, Duncan Gallie, Anton Hemerijck and John Myles.
} 
notions of redirecting investment to children, did not initially meet wide consensus, investment in children and human capital have been part of the EU's general strategy since 2005 (Jenson 2010b, 12, 26).

Ideas underscoring the need to include the social investment perspective in the EU were once more put forth with an opinion paper in 2011. Bruno Palier, professor at l'Institut d'études politiques in Paris, explains how he became a part of that opinion paper. ${ }^{8}$ Palier had previously worked on understanding and appraising how European nations had used social investment as a strategy in the past with Nathalie Morel and Joakim Palme (Morel et al. 2009). This work had the goal of improving the coherence of the perspective and providing a framework for welfare state reform (Ibid., 9). The conclusions from that project eventually led Palier to work with Vandenbroucke and Hemerijck to publish, "The EU Needs a Social Investment Pact" in 2011 (Vandenbroucke et al.).

In this paper, the authors highlight issue areas for the EU's social dimension; many of these concerns would later be found in the European Parliament's resolution for the Social Investment Pact. The policy paper voices concern toward the place (or lack thereof) of social policy in the new macroeconomic and fiscal surveillance provisions adopted by the EU to handle difficulties related to the global recession and the sovereign debt crisis. One of the key points of the paper is that, "Consistent delivery of the social investment objectives requires that they be embedded in the macroeconomic and budgetary surveillance of the EU" (Ibid., 15). Accordingly, the authors also emphasize the importance of "supply side instruments" to meet new social risks including, childcare, reconciling work and family life, the integration of migrants and minimum income support (Ibid., 9). The authors also explain the need to go beyond soft governance to ensure that "short term macroeconomic governance serves long-term social investment" (Ibid., 18). In their view, a policy of a social investment pact is a possible solution that would encourage reciprocity between Member States (Ibid., 20).

On November 20, 2012, the European Parliament adopted a resolution highlighting the need for a social pact enabling employment activation and investing in youth (European Union 2012b). This resolution specifically calls for a pact for "better governance", "reinforced control", and "a regular surveillance framework" (European Union 2012b). Three months after the parliamentary resolution, the European Commission - who had also been working on a social investment initiative - adopted the Social Investment Package (SIP) (European Commission 2013d). The SIP, accompanied by the recommendation "Investing in Children" and a series of working documents, is a reaction to the EU's long-term structural problems (European Union 2013d, 3-8). It emphasizes the effects of demographic change and inequality in society, and the need for inclusive growth in the job market (Ibid., 8). The SIP therefore aims to enhance coordination and political efficiency with regards to: activation policies, workforce training, preschool services, education, housing, rehabilitation services, and healthcare (European Union 2013d, 9).

Approved by both the Commission and Parliament in May of 2013, the Package does not reflect all the demands made by the EU Parliament and experts. The SIP is neither integrated in the European Semester through the Annual Growth Survey (AGS) or the National Reform Programs, nor does it stipulate precise targets or a timetable. This means the SIP does not have the legal force to impose sanctions to noncooperative Member States (Kvist 2013, 92). This is a key difference. The governance structure advocated

\footnotetext{
${ }^{8}$ Interview Bruno Palier (professor at l'Institut d'études politiques in Paris), in telephone conversation with author, Paris, France, August 28, 2013.
} 
by experts and the EU Parliament has been changed from the proposed pact to a package. Whereas a pact is a solemn agreement or treaty and would indicate reciprocity between Member States, a package is a combination of propositions oriented around a general theme. The social packages adopted by the EU therefore do not have the same constraining force as pacts do. A similar phenomenon in EU terminology is the creation of platforms, a term that carries an experimental connotation and is used to indicate initiatives based on a central theme (Daly 2012, 276). The European Union's apparent preference is to adopt soft packages and platforms for social initiatives as opposed to pacts, which are more commonly adopted for economic and financial measures. Finally, the SIP does not have a detailed budget for the rest of the Europe 2020 period, from 2014-2020 (European Union 2013b). For these reasons, the Commission will need to create a long-term agenda for investment if it wants the SIP to be an effective framework for the social dimension (OSE Podcast 2013).

The SIP does address pressing new social risks, including demographic changes, the end of the male breadwinner model, and early childhood investment. For instance, the recommendation "Investing in Children" links the reduction of poverty and social exclusion to childhood stability (the work-family balance), and access to education and healthcare (European Union 2013e). Nonetheless, the SIP is also inconsistent with elements of the social investment perspective because it is not a holistic policy with precise targets. This can also be explained by the fact social investment has been grafted or added in "layers" and "conversions" to welfare states instead of being implemented as a new cohesive model (Jenson 2012, 62; Palier 2010, 366-369). European states therefore only gradually adapt their social systems in phases over the years. This may create similar changes to common structural problems, while maintaining nonnegligible differences between states as a whole. The adoption of activation policies offers a good illustration of this phenomenon. Nordic countries use flexicurity to encourage activation, whereas liberal regimes encourage activation using workfare-type measures (Palier 2014). In this case, faced with a common problem both states adopted policies based in the social investment perspective. However, each specific policy may have differing effects on their welfare models and may give way to different ideas for change.

The EU's social initiatives that use cooperative governance, including the SIP, have precisely the same effect of consolidating best practices without providing a clear framework to attain common objectives. This flexibility is both a blessing and a curse for the SIP. The package gives overall common objectives to social problems that clearly align with the social investment perspective, which allows for Member States to invest to different degrees and not be overly constrained by the Union. However, this course of action is also detrimental in that it approach creates social investment rhetoric, without creating any equalization between the Member States (Kvist 2013,98). This critique has recently been confirmed by a policy report that identifies three clusters of countries according to the degree the SIP has been implemented (Bouget et al. 2015). The authors demonstrate that only 13 of the 28 Member States can be qualified as "maintaining an (often historically) well-established social investment approach" (Ibid., 8). Furthermore, even between these "social investment" countries, strategies vary widely. This brings us to an uncomfortable truth with the social investment perspective: in the context of austerity, social reforms promoted in the European Semester can actually take the form of indiscriminate cuts in social budgets. In this context, certain experts 
go as far as to demand radical reforms to force a paradigm change or at least promote a more holistic approach (Lundvall et al. 2010, 348). ${ }^{9}$

Many policy experts and social partners have weighed in on the issue of whether the policies adopted have successfully promoted employment and inclusion among the most at-risk sections of the population. The next section is an analysis of expert opinions on the SIP followed by more general critiques of the social investment perspective.

\section{Expert Hesitation Toward the SIP}

Reactions to the Social Investment Package (SIP) have been mixed, while advocates of the social investment perspective remain cautiously optimistic towards the package. The following section presents a collection of expert opinions. The European Anti-Poverty Network (EAPN), and the European Trade Union Confederation (ETUC) both provide the most global analyses of the SIP. The EAPN's and the ETUC's positions overlap, but they also reflect two types of arguments that are echoed by experts. The first set of arguments, which the EAPN supports, is critical of social investment without social protection and the SIP's content (or lack thereof). Arguments of this nature note that social investment policies neither sufficiently redistribute nor protect citizens against exclusion and poverty. The second set of arguments, supported by the ETUC among others, adheres to the concept of social investment, but critiques structural tensions apparent in the EU, and the lack of budgetary and symbolic commitment.

The EAPN criticizes the SIP for many reasons, the most apparent of which is the flagrant contradiction between policies of economic austerity and employment activation and investment (EAPN 2013, 6, 11). The welfare state is being tested during a time of austerity, which means states are asked to reduce their social budgets without being able to adopt new initiatives to replace them. This leads to irreconcilable differences between neoliberal policies for macroeconomic stability and the need for social investment in a time of crisis (Hemerijck 2012, 54). The EAPN also criticizes the lack of social protection in the SIP, an essential compliment to investment (EAPN 2013,6). Without strict guidelines to protect the population, the types of modernization policies included in the SIP can actually reduce social spending while still being categorized as social investment. Moreover, the SIP is primarily made of working documents (which have a low legal standing), thus giving the impression that the SIP is not a European priority (Ibid., 6). The EAPN explains the need for the SIP to be integrated into European Semester and to find new balance between social and economic policies (Ibid.).

The need for balance between policy branches is an opinion shared by the ETUC, the European Parliament and experts alike (ETUC 2013; Natali et al. 2013, 256; Vandenbroucke et al. 2011, 14,18; Zeitlin 2010, 262; OSE Podcast 2013). While the ETUC is in agreement with concept of social investment, it condemns the SIP's lack of sufficient budgetary resources and demands "real" investment (2013). The ETUC furthermore requests that the European Commission go beyond recommendations and integrate more balance between social, macroeconomic and financial governance (2013). While maintaining Member States retain sovereignty over social policy, the ETUC underscores the need for quality employment, as well as impact assessments and integrated strategies when promoting social investment (2013).

\footnotetext{
${ }^{9}$ Interview with Cécile Barbier (senior researcher at the European Social Observatory), in conversation with author, Brussels, Belgium, August 29, 2013.
} 
Turning to individual expert reviews of the SIP, Lieve Fransen, former Director for Social Policy for the European Commission's Directorate General for Employment, Social Affairs and Inclusion (DG EMPL), states she is satisfied with the package because she believes balance can be struck if modifications are made. Fransen defends her opinion by arguing the SIP addresses pressing needs, such as demographic change, unemployment and poverty (OSE Podcast 2013). ${ }^{10}$ As a key player in the implementation of this policy initiative, Fransen was working with László Andor, ${ }^{11}$ on linking the SIP's objectives to the Europe 2020 Strategy and the Annual Growth Survey (AGS), at the time of the interview. ${ }^{12}$ In so doing, she believed the SIP's recommendations would be incorporated into the EU's current governance mechanisms and easily integrated to the European Semester. ${ }^{13}$ Fransen's strategy for improving the SIP can be likened to Jonathan Zeitlin's idea of reinforcing the social dimension by tying European social objectives to the Europe 2020 Strategy and using indicators of reference to compare progress between Member States $(2010,269)$. Despite having a clear strategy, the task of rebalancing social investment is complex for many reasons, including the role of political power games between Member States, sharp economic, social and regional divisions, the immense power given to Ministers of Finance and economic councils, and the need for reliable indicators to defend ideas of social investment. ${ }^{14}{ }^{15}$ As Fransen explains, the European Commission can act as a facilitator for the adoption of policies by Member States, however without partnerships and a means of influence over the Member States it is an uphill battle (OSE Podcast 2013). She believes that even if political consensus existed, achieving the SIP's objectives is highly problematic without having reliable indicators. ${ }^{16}$

Frank Vandenbroucke, representative to the Belgian Presidency of the EU in 2001, is of the same mind and defends this perspective by drawing on his knowledge of European politics and institutional hurdles. He explains that multidimensional indicators capable of demonstrating the diverging welfare models and needs among Member States are essential to creating effective social investment. ${ }^{17}$ Similarly to the EAPN, Vandenbroucke believes social investment and protection must be used together to promote the EU's social dimension. However, he opines that even if the SIP can only be considered a soft policy and does not represent the pact declared necessary in his opinion paper, it is a good first step because it launches a nuanced debate on the need for balance between economic and social policy within the EU. ${ }^{18}$

A final expert opinion comes from Bruno Palier, professor at l'Institut d'études politiques in Paris. Using an incremental approach, Palier supports the SIP. In his opinion, durable political change comes in the form

\footnotetext{
${ }^{10}$ Interview with Lieve Fransen (former Director for Social Policy for the European Commission's Directorate General for Employment, Social Affairs and Inclusion (DG EMPL)), in conversation with author, Brussels, Belgium, July 22, 2013.

${ }^{11}$ László Andor is the former Commissioner for Employment, Social Affairs and Inclusion from 2010 to 2014.

${ }^{12}$ Fransen, in conversation with author, July 22, 2013.

13 Ibid.

${ }^{14}$ Adopting an organization composition as described by Hartlapp et al. 2014., the European Commission is no longer a unitary actor, but each DG can adopt either a technocratic, competence-seeking or policy-seeking approach.

${ }^{15}$ Fransen, in conversation with author, July 22nd 2013.

${ }^{16}$ Ibid.

${ }^{17}$ Vandenbroucke, in conversation with author, Brussels, Belgium, July 17, 2013.

18 Ibid.
} 
of incremental steps rather than revolutionary change. ${ }^{19}$ Following this logic, the SIP must be improved upon to reconcile certain economic and social aspects, such as the contradiction between economic austerity and social investment (OSE Podcast 2013). Palier cites the EU's multiple investment programs in youth while at the same time encouraging the younger generation to accept low quality jobs as one major inconsistency in the current social investment scheme (OSE Podcast 2013). He also believes that there would be a better implementation of the SIP if the EU's social and economic committees' worked together and shared competences (OSE Podcast 2013). Finally, the lack of constraining force and precise budget allocations are severe problems for the SIP. As it is not a pact, this initiative reinforces the current imbalance between economic and social policy as well as making the EU's social dimension more complex and possibly inefficient (OSE Podcast 2013). The lack of budgetary planning for the SIP also gives the impression that it is not a serious policy (OSE Podcast 2013). These critiques appropriately complement those made by the EAPN and Lieve Fransen.

In spite of the preceding critiques, not all aspects of the SIP are negative. The recommendation "Investing in Children" receives favourable reviews from both Fransen and Vandenbroucke as being particularly well written. ${ }^{20} 21$ This is especially pertinent to the social investment perspective as the recommendation grounds itself in the ideas generated during the EU's Portuguese Presidency in 2000 (Jenson 2010b, 25). Moreover, the theme of investing in and protecting children opens the door to further initiatives like minimum income, gender equity and pension reform (Ibid., 24-25; Esping-Andersen 2002, 6-10). Adding these provisions in the European dialogue by way of a recommendation supports Palier's idea that changing the EU's social dimension is indeed an incremental process.

\section{Obstacles to Cohesive Social Investment}

As the previous section demonstrates, the EU has incorporated the social investment perspective into its social dimension. However, the transition remains difficult. Four main obstacles can explain this: 1) the inherent structural tension between social and economic policy in the European Union; 2) political ambivalence toward the European social model; 3) conflicting opinions between experts promoting the social investment perspective; and 4) experts who disagree that social investment instruments are appropriate tools to address social risks.

As mentioned throughout this paper, the first obstacle to the SIP is that the EU's social policy is not a unilateral competence and social measures often confront tension with economic priorities. Limited by its supranational composition, the Union cannot unilaterally apply a strict welfare state model to the Member States, as that would infringe on the basic right of national sovereignty (de la Porte 2012, 125). Furthermore, imposing a single model would be highly unfeasible due to varying national welfare regime characteristics. The EU is continually confronted by the intrinsic tension between legal, technical and political elements that has led to the social dimension having to struggle to strike a balance in a changing economic and societal landscape. According to Ross, the "lack of Community-level social policy prerogatives" and conflicting Member State positions on what role the EU should play on social policy are major structural

\footnotetext{
${ }^{19}$ Palier, in telephone conversation with author, Paris, France, August 28th 2013.

${ }^{20}$ Fransen, in conversation with author, July 22nd 2013.

${ }^{21}$ Vandenbroucke, in conversation with author, July 17, 2013.
} 
obstacles $(2011,44)$. All EU social policy initiatives will continue to be confronted by such issues until more clarity is achieved on the balance between the EU and Member States on the social dimension.

Whether or not social policy experts are satisfied with the EU's social dimension, many cite political ambivalence as another obstacle for the European social model and the incorporation of the social investment perspective (Natali et al. 2013). ${ }^{22}{ }^{23}$ This problem is exacerbated by the reoccurring theme of adopting soft measures. In this case, the adoption of a package and not a pact. While economic policies often have constraining force, social policies are not implemented in the same manner. This is often interpreted as a reticence or non-endorsement of the policies. At the root of this problem lies political acrimony.

One interviewee, a member of the Directorate General for Employment, Social Affairs and Inclusion (DG EMPL), attributes former European Commission President José Manuel Barroso's "hot and cold" behaviour toward the social dimension as a limit to social initiatives and the cause of confusion between civil servants. ${ }^{24}$ Another member of DG EMPL indicates the Commission's-President Barosso's belligerent stance toward the European Council and its former president Herman Van Rompuy (2009 to 2014) - as another grave problem. ${ }^{25}$ This is not the first time President Barosso has been perceived as holding Europe's social dimension back. In fact, he was one of the leading figures in the reorientation of the Lisbon Strategy in 2005 toward job creation and economic growth and away from other social aspects (Lundvall et al. 2010, 337). The same civil servant explained that these conflicts reduce the flexibly for the various work committees, and render many results arbitrary to the Commission's will. ${ }^{26}$ This last point is crucial, not only to any advance in social policy, but the functioning of measures already in place.

Admittedly, political opposition reduces the ability of committee's to to act in the domains they were precisely created to work within. To illustrate, the Social Protection Committee (SPC) is meant to "monitor social conditions" and "promote the discussion and coordination of policy approaches", however it has no legal mandate to advise on pensions or social inclusion because it was not included in the Europe 2020 Strategy or the Annual Growth Survey (European Union 2013h). ${ }^{27}$ According to some, this mistake was intentional. Evidence of a policy seeking rational and power games exist not only between the economic and social dimensions, but also among the various employment and social committees (such as EMCO and SPC) (Vanhercke 2013; Hartlapp et al. 2014). ${ }^{28}$ Increasing coordination among these committees would therefore be a first important improvement to make to any social policy reform.

Another criticism linked to political ambivalence is the European Commission's lack of transparency.

\footnotetext{
22 Ibid.

${ }^{23}$ Interview with a member of personnel at the Directorate General for Employment, Social Affairs and Inclusion, in conversation with author, Brussels, Belgium, July 27th, 2013.

${ }^{24}$ Interview with a member of personnel at the Directorate General for Employment, Social Affairs and Inclusion, in conversation with author, Brussels, Belgium, May 24th, 2013.

${ }^{25}$ Member of personnel at the Directorate General for Employment, Social Affairs and Inclusion, in conversation with author, Brussels, Belgium, July 27th, 2013.

26 Ibid.

27 Ibid.

28 Ibid.
} 
According to all many interviewees, few documents from the various committees are made public and there is sometimes a plain refusal to give access to documents. This frequently makes analyses of the EU's social dimension impossible. The European Commission's attitude towards this issue gives the impression that it deliberately refuses to inform the public. This last element highlights the need for dialogue to legitimize the population's social policy needs. Public debate and transparency are key to lending weight to expert opinions.

The previous section highlighted the diverging opinions social investment advocates have on the SIP and its contents. However, the social investment perspective is only one option for social policy recalibration and certain policy experts disagree that social investment perspective is the right course of action. To that effect, they find many caveats within the perspective. These critiques take issue with the social investment perspective's emphasis on linking welfare to the economy, which may conceal neoliberal policies and does not adequately protect at-risk segments of the population. Experts also criticize the perspective's emphasis on the long-term.

According to certain social policy experts, in the need to restructure European welfare states, the social investment perspective is used to mask neoliberal ideas. ${ }^{29}$ Barbier, senior researcher at the European Social Observatory, observes that European social policies require in-depth reforms, however no political will to institute such reforms exists. ${ }^{30}$ Unsatisfied by incremental reform, which she believes leads to fragmented policy initiatives with little or no impact, Barbier points out the Union's structural problems. The EU's founding policy architecture is economically oriented, meaning economic priorities are consistently placed above other considerations. As a consequence, the Union remains ill equipped to enforce social policies.

Researchers have also criticized the EU's policies of social investment for not helping the most at-risk segments of the population. Béa Cantillon, policy advisor to the Organization of Economic Coordination and Development (OECD) and the European Commission, argues that there was no poverty reduction under the Lisbon Strategy and explains that asymmetries in the distribution of employment policies benefit classes disproportionately $(2012,445)$. During the Lisbon Strategy, the EU changed its passive transfer-oriented policies and services to focus on policies of activation and employment (Ibid, 445). Low-income families cannot take full advantage of activation policies, which tend to benefit households with two working adults, because their situation requires policies of redistribution and social protection (2012, 445; Cantillon and Van Lancker 2013, 560). The change from passive transfers to activation presents further problems for atrisk groups because not all citizens can be a productive factor. Social inclusion via employment therefore has limited results for all those unable to work (Cantillon and Van Lancker 2013, 556). Furthermore, certain iterations of the social investment perspective emphasize quantity over quality of jobs (Palier 2014, 32; Bonoli 2012).

What is more, social investment policies emphasize the long term and can neglect pressing issues. An example is the social investment perspective's lack of focus on gender equality. Jane Jenson explains that the social investment perspective emphasizes childcare and women's productive role rather than addressing present gender inequality problems $(2008,147)$. The social investment perspective therefore does not necessarily provide adequate protection for all at-risk groups. This highlights the importance of the duality

\footnotetext{
${ }^{29}$ Barbier, in conversation with author, Brussels, Belgium, August 29, 2013.

${ }^{30}$ Ibid.
} 
in the social investment perspective - investment and protection. Unfortunately, as social investment policies are grafted to existing social models they are rarely thoroughgoing. As a case in point, the Social Investment Package (SIP) does not to address the issue of social protection.

These assessments echo many of the European Anti-Poverty Network's (EAPN) opinions of the SIP. According to specialists, the lack of coherence between policies is an inherent weakness of the social dimension (Liddle et al. 2010. 86-88). For experts who remain sceptical of the SIP, the absence of any real legislative power and detailed budgets serves to confirm the fragility of this policy measure. It is important to note that these arguments are not new, European social initiatives are rarely binding and often reallocate funding instead of there being a general increase in social spending.

Finally, the current state of economic instability must also be taken into account in this policy debate. According to some authors, the sovereign debt crisis represents a series of interrelated crises pertaining to unemployment, inequality, the North-South divide, and a political crisis of confidence (Diamond et al. 2012, 287-288; Natali et al. 2013, 105). Consequently, economic instability has not changed the EU's long-term social problems so much as the order in which each dilemma is addressed (Diamond et al. 2012, 303). The EU must therefore choose which social services are essential during a crisis and which ones may be forgone. Following this logic, the EU is reacting in a way that indicates formalizing the social dimension is important but not a priority at this time. Policy experts warn against this. Kvist, for example, cautions that these crises will have varying effects on the EU's population $(2013,105)$. In the long-term, the absence of quality services will be a weight upon today's youth and create important generational differences (Kvist 2013, 105). Experts agree that social investment must not be used to correct the perceived negative effects of policies (as is now happening) but rather to correct market failures and to avoid greater future calamity (Diamond et al. 2012, 289). These debates highlight the need for the EU to take comprehensive social policy seriously.

A classic disparity therefore presents itself between experts: defenders of left-wing policies cannot adhere to a half-hearted social dimension imbedded in neoliberal ideals, whereas, those who defend the social investment perspective in the EU expect change to come "more incrementally than through a social policy revolution" (Palier 2010, 386). For these reasons, one cannot stress enough the importance of continued debate enough within EU institutions and between experts.

\section{Conclusion}

The social investment perspective is perhaps a well-constructed model for the many challenges the European Union and its Member States face. However, 1) the EU's inherent structural tensions between social and economic policy; 2) perceived political ambivalence toward the European social model; 3) conflicting expert opinions regarding the social investment perspective; and 4) disagreement about whether social investment instruments are appropriate tools to address social risks, have plagued the Social Investment Package. Collectively, these obstacles make it difficult to transfer coherent theoretical conceptions to such a highly politicized world. Economic crises also limit the EU's ability to react to a wide array of initiatives, thus reducing the likelihood of implementing effective social investment policies in the short-term. 
European integration was first meant to be economic before eventually adding the political and social dimensions. Accordingly, the EU has been based on neoliberal economic concepts since its creation and often highlights negative integration. Confronted by this, the promotion of constraining social initiatives can easily be blocked and policies robbed of their beneficial effects during the negotiation process. The Union has continued this trend during the economic crises by adopting coercive macroeconomic and financial measures while maintaining soft social policies. The subsequent political games generate further complexities and create irregularities between policy initiatives. It may be said that the social policies adopted depend of the political will of the day, which leads to a great measure of instability and incoherence among strategies. For these reasons, despite the clear presence of the social investment perspective in the EU's rhetoric, experience shows this perspective is having difficulty in becoming part of the European ideology.

Nevertheless, efforts by partisans of the social investment perspective are not entirely in vain. Authors have demonstrated that, despite difficulties, the EU is progressively adopting measures that follow this perspective (Kvist 2013, 92; Palier 2010, 386). From this viewpoint, the Social Investment Package (SIP) represents the most recent - if timid — of a long line of policy initiatives, starting in the 1990s and taking the form of investment in human capital during the life cycle from 2005 onwards (Jenson 2008, 133-135). The Europe 2020 Strategy and the SIP are neither the beginning nor the end of social investment in the EU, but two examples of a much more general trend. The constellation of research centers and think tanks that operate in the EU are a key tool to advancing the social dimension, and central to promoting the rights of disadvantaged groups.

\section{References}

Armstrong, Kenneth, A. 2010. Governing Social Inclusion: Europeanization through Policy Coordination. Oxford: Oxford University Press.

Barbier, Cécile. 2012. "Ordolibéralisme et économie sociale de marché : la voie allemande de l'Europe?". European Social Observatory. Opinion paper No. 10. Online. http://www.ose.be/files/publication/OsePaperSeries/Barbier_2012_OpinionPaper10_O rdoliberalisme_0712.pdf (page consulted July $5^{\text {th }}$ 2013).

Barcevičius, Egidijus, J. Timo Weishaupt and Jonathan Zeitlin (eds). 2014. Assessing the Open Method of Coordination, Institutional Design and National Influence of EU Social Policy Coordination. United Kingdom: Palgrave Macmillan.

Bonoli, Giuliano. 2006. "New social risks and the politics of post-industrial social policies". In Armingeon, Klaus and Giuliano Bonoli, (eds.), Adapting post-war social policies to new social risks. New York: Routledge, 3-26.

2012. "Active labour market policy and social investment: a changing relationship" In Morel, Nathalie, Bruno Palier and Joakim Palme, (eds.), 2012. Towards A Social Investment Welfare State? Ideas, policies and challenges. Bristol: The Policy Press: 153-180. 
Bouget, Denis, Hugh Frazer, Eric Marlier, Sabastiano Sabato, and Bart Vanhercke. 2015. "Social Investment in Europe: A study of national policies". European Commission, European Social Policy Network.

Cantillon, Béa. 2011. "The paradox of the social investment state: growth, employment and poverty in the Lisbon era”. Journal of European Social Policy. Vol. 21(5): 432-449.

Cantillon, Béa and Wim Van Lancker. 2013. "Three Shortcomings of the Social Investment Perspective". Social Policy and Society Vol. 12(4):553-564.

Daly, Mary. 2012. "Paradigms in EU social policy: a critical account of Europe 2020". European Review of Labour and Research. Vol.18(3) : 273-284.

De la Porte, Caroline and Kerstin Jacobsson. 2012. "Social investment or recommodification? Assessing the employment policies of the EU Member States". In Morel, Natalie, Bruno Palier and Jaokim Palme, (eds.), Towards a Social Investment Welfare State? Ideas, policies and challenges. Bristol: The Policy Press, 117-149.

De la Porte Caroline and Philippe Pochet. 2012. "Why and how (still) study the Open Method of Coordination (OMC)?” Journal of European Social Policy. Vol. 22(3): 336-349.

Diamond, Patrick and Roger Liddle. 2012. "Aftershock: the post-crisis social investment welfare state in Europe". In Morel, Nathalie, Bruno Palier and Joakim Palme, (eds.), Towards a Social Investment Welfare State? Ideas, policies and challenges. Bristol: The Policy Press, 285 - 308.

Esping-Andersen, Gøsta. 1990. The Three Worlds of Welfare Capitalism. Princeton: Princeton University Press. Press. 1999. Social Foundations of Postindustrial Economies. Oxford: Oxford University 2002. “Towards the Good Society Once Again?”. In Esping-Andersen, Gøsta, Duncan Gallie, Anton Hemerijck and John Myles, (eds.), Why we need a new welfare state. Oxford: Oxford University Press, 1-25.

Esping-Andersen, Gøsta, Duncan Gallie, Anton Hemerijck and John Myles. 2001. “A New Welfare Architecture for Europe." Report Sumbitted to the Belgian Presidency of the European Union.

Esping-Andersen, Gøsta, Duncan Gallie, Anton Hemerijck and John Myles, (eds.). 2002. Why we need a new welfare state. Oxford: Oxford University Press.

European Trade Union Confederation (ETUC). 2013. "The Social Investment Package". Online http://www.etuc.org/sites/www.etuc.org/files/SIP_EN_Final_Resolution_2.pdf (page consulted February 17th 2015). 
European Trade Union Institute (ETUI). 2013. Benchmarking Working Europe 2013. Brussels: ETUI aisbl.

EurActiv. 2013. EU leaders debate youth jobs in Berlin 'show summit'. 04/07/13. Online. http://www.euractiv.com/innovation-enterprise/eu-leaders-debate-eu-youth-jobs-news$\underline{529091}$ (page consulted July 1. 2013).

Europa. 2014. Synthèses de la législation. Open Method of Coordination. Online. http://europa.eu/legislation_summaries/glossary/open_method_coordination_en.htm (page consulted January 19, 2015).

European Anti-Poverty Network (EAPN). 2012. An EU worth defending: beyond austerity to social investment and inclusive growth. Online. http://www.eapn.eu/images/stories/docs/EAPN-position-papers-and-reports/2012-eapnnrp-report-en.pdf (page consulted August 22, 2013).

. 2013a. "EAPN Response to the Social Investment Package : Will it reduce poverty ?". EAPN Position Paper. Online. http://www.eapn.eu/images/stories/docs/EAPN-positionpapers-and-reports/2013-EAPN- Response-to-the-SIP-en.pdf (page consulted June 13, 2013).

European Union. European Commission. 2013a. Europe 2020. Online. http://ec.europa.eu/europe2020/index_fr.htm (page consulted August 5, 2013). . 2013b. Protection sociale et inclusion sociale. Online.

http://ec.europa.eu/social/main.jsp?catId=750\&langId=fr (page consulted August 5, 2013). .2013c. Communiqué de presse : Entrée en vigueur du Two-Pack. Online. http://europa.eu/rapid/press-release_MEMO-13-457_fr.htm (page consulted May 28, 2013).

. 2013d. Communication from the Commission to the

European Parliament, the Council, the European Economic and Social Committee and the Committee of the Regions. COM(213)82 final. Brussels. Online. www.ec.europa.eu/social/BlobServlet?docId=9761\&langId=en (page consulted June 12, 2013).

.2013e. Investing in children: breaking the cycle of disadvantage. COM(2013) 778 final. Brussels: Commission européenne.

.2013h. Social Protection Committee. Online. http://ec.europa.eu/social/main.jsp?catId=758 (page consulted December 7, 2013).

European Union. Eur-Lex. 2010. “Traité sur le fonctionnement de l'Union européenne”. Online. http://eur-lex.europa.eu/LexUriServ/LexUriServ.do?uri=OJ:C:2010:083:FULL:FR:PDF 
(page consulted August 5th 2013).

European Union. Eurofound. 2013h. About Eurofound. Online.

http://www.eurofound.europa.eu/about/index.htm (page consulted September 25, 2013)

European Union. European Parliament. 2012b. Social Investment Pact-as a response to the crisis. 2012/2003/(INI). Online.

http://www.europarl.europa.eu/oeil/popups/summary.do? $\mathrm{id}=1234849 \& \mathrm{t}=\mathrm{d} \& \mathrm{l}=\mathrm{en}$ (page consulted June 12, 2013).

Feigl, Georg, Sven Hergovich and Miriam Rehm. 2013. "Beyond GDP : can we re-focus the debate?". In Natali, David and Bart Vanhercke, (eds.), Social developements in the European Union 2012. Brussels: ETUI aisbl. and Ose, 63-89.

Giddens, Anthony. 1998. The Third Way: The Renewal of Social Democracy. Polity Press: Cambridge.

Hartlapp, Miriam, Julia Metz and Christian Rauh. 2014. Which Policy for Europe? Power and Conflict Inside the European Commission. Oxford University Press: Oxford.

Hemerijck, Anton and Ive Marx. 2010a. "Continental Welfare at a Crossroads: The Choice Between Activation and Minimum Income Protection in Belgium and the Netherlands". In Palier, Bruno, (ed.), A Long Goodbye to Bismarck? The politics of welfare reform in continental Europe. Amsterdam: Amsterdam University Press, 129-156.

Hermerijck, Anton and Werner Eichhorst. 2010b. "The Adaptive Capacity of the Continental Welfare State". In Palier, Bruno, (ed.), A Long Goodbye to Bismarck? The politics of welfare reform in continental Europe. Amsterdam: Amsterdam University Press, 301-332.

Hemerijck, Anton. 2012. “Two or three waves of welfare state transformation?”. In Morel, Natalie, Bruno Palier and Joakim Palme, (eds.), Towards a Social Investment Welfare State? Ideas, policies and challenges. Bristol: The Policy Press, 33-60.

Jenson, Jane. 2008. "Writing women out, folding gender in. The European Union 'modernises' social policy”. Social Politics. International Studies in Gender, State and Society. Vol. 15(2): 1-23.

. 2010a. "Diffusing Ideas for After Neoliberalism: The Social Investment Perspective in Europe and Latin America “. Global Social Policy. Vol.10 (1): 59-84.

. 2010b. "Ideas and Policy: The European Union Considers Social Policy Futures". American Consortium on European Union Studies. ACES Cases, No. 2010.2: 1-33.

.2012. "Redesigning citizenship regimes after neoliberalism”. In Morel, Natalie, Bruno Palier and Joakim Palme, (eds.), Towards a Social Investment Welfare State? Ideas, policies and challenges. Bristol: The Policy Press, 61-87. 
Jenson, Jane and Denis Saint-Martin. 2003. "New Routes to Social Cohesion? Citizenship and the social investment state". Canadian Journal of Sociology. Vol. 28(1): 77-99.

Kingdon, John W. 1984. Agendas, Alternatives, and Public Policies. Boston: Little Brown.

Kvist, Jon. 2013. "The post-crisis European social model: developing or dismantling social investments?". Journal of International and Comparative Social Policy. Vol. 29(1): 91- 107. Online. http://dx.doi.org/10.1080/21699763.2013.809666 (page consulted August 5, 2013).

Liddle, Roger, Patrick Diamond, Simon Latham and Tom Brodie. 2010. "Aftershock: The Coming Social Crisis in the EU”. In Marlier, Eric, David Natali and Rudi Van Dam, (eds.), Europe 2020 Towards a More Social EU? Brussels: P.I.E. Peter Lang, 69-92.

Lindblom, Charles E. 1959. "The Science of 'Muddling Through"”. Public Administration Review. Vol. 19(2): 79-88.

Lundvall, Bengt-Ake and Edward Lorenz. 2010. "From the Lisbon Strategy to Europe 2020”. In Morel, Natalie, Bruno Palier and Joakim Palme, (eds.). Towards a Social Investment Welfare State? Ideas, policies and challenges. Bristol: The Policy Press, 33-352.

Marlier, Eric, David Natali and Rudi Van Dam, (eds.). 2010. Europe 2020 Towards a More Social EU? Brussels: P.I.E. Peter Lang.

Morel, Nathalie, Bruno Palier and Joakim Palme, (eds.). 2009. What Future for Social Investment? Stockholm: Institute for Futures Studies Research Report. .2012. Towards A Social Investment Welfare State? Ideas, policies and challenges. Bristol: The Policy Press.

Natali, David and Bart Vanhercke, eds. 2013. Bilan social de l'Union européenne 2012. Brussels: ETUI aisbl. and Ose.

Notre Europe, Institut Jacques Delors. 2013. “Towards a more social Europe?". Summary of the event. Online. http://www.notre-europe.eu/011-16353-Towards-a-more-social-Europe.html (page consulted July 12, 2013).

OSE Podcast. Palier, Bruno and Lieve Fransen. 2013. "Social Investment Package: Just Hype or the Next Big Thing?”. Ose Lunchtime Session. 11/03/13. Online. http://www.ose.be/FR/publications/podcast.htm (page consulted August 27, 2013).

Palier, Bruno, (ed.) 2010. A Long Goodbye to Bismarck? The politics of welfare reform in continental Europe. Amsterdam: Amsterdam University Press. . 2014. "La stratégie de l'investissement social". Les éditions des journaux officiels. France. 
Peña-Casas Ramón. 2013. "Desperately seeking the European Employment Strategy in the new economic governance of the European Union". In Natali, David and Bart Vanhercke, (eds.), Social developments in the European Union 2012, Brussels: ETUI aibsl. and Ose, 123-145.

Rhodes, R.A. 1996. "The New Governance: Governing without Government.” Political Studies 44(4): 652-667.

Ross, George. 2011. The European Unions and its Crises: Through the Eyes of the Brussels Elite. New York: Palgrave Macmillan.

Sabel, C.F., and Jonathan Zeitlin. 2008. "Learning from difference: the new architecture of experimentalist governance in the EU". European Law Journal. Vol. 14(3): 271-327.

Saint-Martin, Denis. 2004. "Coordinating Interdependence: Governance and Social Policy Redesign in Britain, the European Union and Canada." Canadian Policy Research Networks. Research Report $\mathrm{F} \mid 41$.

. 2000. "De l'État-providence à l'État d'investissement social: Un nouveau paradigme pour enfant-er l'économie du savoir?" In Pal, Leslie A. (ed.), How Ottawa Spends 20002001: Past Imperfect, Future Tense

The Greens. 2013. "EU Cohesion Policy 2014-2020”. European Free Alliance. 10/07/13. Online. http://www.greens-efa.eu/eu-cohesion-policy-2014-2020-10331.html (page consulted August 1, 2013).

Tömmel, Ingeborg. 2009. "Modes of Governance and the Institutional Structure of the European Union.” In Tömmel, Ingeborg and Amy Verdun (eds.), Innovative Governance in the European Union: The Politics of Multilevel Policymaking. Colorado: Lynne Rienner Publishers.

Tömmel, Ingeborg and Amy Verdun (eds.). 2009. Innovative Governance in the European Union: The Politics of Multilevel Policymaking. Colorado: Lynne Rienner Publishers.

TURI, Trade Union related research institutes. 2015. "The European Social Observatory." Online. http://www.turi-network.eu/Members/Full-members/European-Social-ObservatoryOSE-Centre-for-research-and-information-on-the-social-implications-of-European-integration (page consulted November $1^{\text {st }} 2015$ ).

Vandenbroucke, Frank, Bruno Palier and Anton Hemerijck. 2011. "The EU Needs a Social Investment Pact ". Ose Paper Series, No. 5. Online. http://www.ose.be/FR/publications/ose_paper_series.htm (page consulted June 5, 2013).

Vanhercke, Bart. 2013. "Flying Under the Radar? EU social Policy in Times of Austerity". In Natali, David and Bart Vanhercke, (eds.), Social developments in the European Union 2012. Brussels: ETUI aisbl. and Ose, 91-121. 
Zeitlin, Jonathan. 2010. "Towards a Stronger OMC and a More Social Europe 2020". In Marlier, Eric, David Natali and Rudi Van Dam, (eds.), Europe 2020 Towards a More Social EU?, Brussels: P.I.E. Peter Lang, 253-273.

Zeitlin, Jonathan, Barcevičius, Egidijus, J. Timo Weishaupt. 2014. "Institutional Design and National Influence of EU Social Policy Coordination: Advancing a Contradictory Debate.” In Barcevičius, Egidijus, J. Timo Weishaupt and Jonathan Zeitlin (eds), Assessing the Open Method of Coordination, Institutional Design and National Influence of EU Social Policy Coordination. United Kingdom: Palgrave Macmillan.

\section{Appendix}

List of Abbreviations

\begin{tabular}{l|l}
\hline Abbreviation & Institution \\
\hline AGS & Annual Growth Survey \\
\hline CSR & Country Specific Recommendation \\
\hline DG ECFIN & Directorate General for Economic and Financial Affairs \\
\hline DG EMPL & Directorate General for Employment, Social Affairs and Inclusion \\
\hline EMCO & Employment Committee \\
\hline EPC & Economic Policy Council \\
\hline EPSCO & Employment, Social Policy, Health and Consumer Affairs Council \\
\hline NRP & National Reform Programs \\
\hline OMC & Open Method of Coordination \\
\hline SPC & Social Protection Committee
\end{tabular}


Published by the Centre for European Studies at Carleton University, Ottawa, Canada Available online at: journals.carleton.ca/rera/index.php/rera

RERA is an electronic academic peer-reviewed journal. Topics relate to the European Union, it's Member States, the former Soviet Union, and Central and Eastern Europe. The journal is a joint project supported by the Canada-Europe Transatlantic Dialogue - a cross-Canada research network supported by the Social Sciences and Humanities Research Council of Canada (SSHRC) - along with the Institute of European, Russian and Eurasian Studies (Carleton University) and its associated research unit, the Centre for European Studies.

RERA aims to provide an accessible forum for research, to promote high standards of research and scholarship, and to foster communication among young scholars.

\section{Contact:}

Carleton University

The Centre for European Studies

1103 Dunton Tower

1125 Colonel By Drive

Ottawa, ON K1S 5B6

Canada

Tel: +01 613 520-2600 ext. 3117; E-mail: rera-journal@ carleton.ca

\section{Creative Commons License}

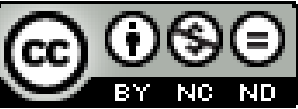

creativecommons.org/licenses/by-nc-nd/3.0

This Working Paper is licensed under a Creative Commons Attribution-Non-CommercialNo Derivs 3.0 Unported License (CC BY-NC-ND 3.0).

Articles appearing in this publication may be freely quoted and reproduced, provided the source is acknowledged. No use of this publication may be made for resale or other commercial purposes.

ISSN: 1718-4835

(C) 2016 The Author(s) 